\title{
Language rights and groups of immigrant origin
}

\author{
The case of language claims \\ in the Spanish cities in North Africa
}

\author{
Iker Erdocia \\ Dublin City University
}

\begin{abstract}
In this article, I aim to analyse language rights in relation to groups of immigrant origin. Liberal democracies are reluctant to consider immigrant groups as subjects entitled to the same set of language and cultural rights enjoyed by national minorities. However, the trend towards increasing levels of immigration is configuring new cultural and language correlations within territorial boundaries that provoke responses that problematise a fixed conception of language rights. Drawing on theories of liberal multiculturalism, I examine the case of claims for language recognition in the Spanish autonomous cities of Ceuta and Melilla and its normative implications. In these territories, factors such as size, concentration, and the historical ties of Arabic- and Berber-speaking communities challenge conventional approaches to minority groups' rights based on a national versus immigrant minority distinction. I argue that these approaches are not satisfactory for language claims in these two cities and that a contextual approach is better suited to conceptualising the recognition of language rights.
\end{abstract}

Keywords: language rights, language claims, language policy, migration, political theory, multiculturalism, contextualism

\section{Introduction}

Western societies are witnessing social changes with potential effects on the minority rights debate. More specifically, increasing immigration is configuring new cultural and language correlations within territorial boundaries which provoke responses that might challenge discourses on language rights. By way of example, in 2002 the Arab activist Dyab Abou Jahjah prompted a considerable public controversy in Belgium by demanding that Arabic should be the fourth 
official language in Belgium for reasons of demographic weight (Osborn 2002). In 2011, President Erdogan announced that forced integration is against international law and suggested that Turks in Germany should learn Turkish first (Pidd 2011). In this article, I examine one of the most significant cases of claims for language recognition in the European ${ }^{1}$ context: the autonomous cities of Ceuta and Melilla. In these Spanish territories, factors such as the size, concentration and historical ties of Arabic- and Berber-speaking communities lead to questions about how suitable conventional approaches to minority groups' rights based on a distinction between national and immigrant languages are.

To this end, this article is grounded in the recent interest of political philosophers in linguistic justice and language rights (e.g. Kymlicka \& Patten 2003a; De Schutter 2007; Van Parijs 2011). More precisely, it lies within the emerging notion of 'normative language policy' (Ricento et al. 2015, Peled 2014; Léger \& Lewis 2017), an interdisciplinary field within which sociolinguistics and political theory converge to address the moral implications of real-world language policy and planning matters (e.g. Oakes 2017, Oakes \& Peled 2018). In line with this applied scholarly work, my aim is to analyse the case of the two enclaves and to explore how the language claims of Arabic and Berber groups challenge the foundations of existing normative approaches based on the dominant national/immigrant analytical categories. I also aim to make a contribution to strengthening the theoretical basis for contextual approaches to normative language policy.

I proceed in three steps. First, I begin by describing the context with a particular emphasis on the historical, political, and legal dimensions of language claims. Secondly, bearing in mind the empirical evidence that liberal democracies are reluctant to consider immigrant groups as subjects entitled to the same set of language and cultural rights enjoyed by national minorities, I turn to liberal political theories of multiculturalism and minority rights to get a normative insight into this distinction. More concretely, I scrutinise the theoretical foundations of what I term the 'discrete approach', developed by Kymlicka (1995) and Patten (2003, 2014), and I outline the mismatch between the implications of that work and the contextual factors of the case study. Methodologically, following a problemdriven approach and adopting a context-sensitive ethical enquiry, I assume that the examination of linguistic justice requires immersion in individuals' particular contexts rather than abstraction from them (Carens 2000). My discussion adopts the contextual shift undergone by contemporary political thought according to which political practices have been woven into normative arguments (Choudhry

1. The use of the adjective "European" refers not to geography, since Ceuta and Melilla are on the African continent, but to the fact that these two enclaves, being politically part of Spain under international law, are by implication part of the European Union. 
2002). This fact, along with my intention to integrate a normative perspective into a real-life setting, have led the focus of my analysis. Thirdly, in the final section of the article, drawing on recent advances in contextual political theory, I conclude by outlining how a contextual approach helps to reconceptualise the recognition of minority groups' rights and by discussing the lessons which can be drawn from the case study. In a nutshell, I argue that: (a) theoretical accounts based on group-differentiated rights are not satisfactory for language demands by Arabic and Berber communities; and (b) that, while I acknowledge that the conditions in Ceuta and Melilla are rather unique, I defend the claim that the consideration of contextual facts and principles is the best response to language claims.

\section{The context}

\section{Historical shape of Ceuta and Melilla}

Located in the north of the African continent, the enclaves of Ceuta and Melilla represent a political exception in terms of Spanish sovereignty outside its peninsular territory. The origins of this can be traced to the 15th century, when Europeans took control of these two areas: Melilla was first ruled by the Castilian Crown in $1497 ;^{2}$ and two centuries after its conquest by the Portuguese in 1415 , Ceuta was finally annexed to Spain in 1668. Shaped by centuries of historical and political vicissitudes under Spanish military rule, it was not until the zoth century that the cities acquired a completely civil dimension. Since then, Ceuta and Melilla have been marked by continuous multidirectional flows of people from different ethnic, religious, and linguistic backgrounds: mainland Spaniards, Riffian Berbers and, to a much lesser extent, Sindhi Hindus and Sephardic Jews. Nowadays, the cities each have a population of about 85,000 .

From a jurisdictional point of view, Morocco claims sovereignty over the two cities together with a few other small territories also under Spanish control, although none of them are included in the UN decolonisation list. The Spanish Constitution of 1978 envisaged the possibility that they could become autonomous cities. Later, in 1986, an important event took place: a reorientation of the Spanish Law on Foreigners (7/1985) regularised the presence of thousands of Moroccan nationals, by granting them citizenship. At that time, $32 \%$ of the population in Melilla and $18 \%$ in Ceuta had an origin other than the Iberian peninsula (INE 1987). This regularisation was formalised in the aftermath of months of

2. It is noteworthy that despite its unusual geographical location, Spanish rule of the city of Melilla (1497) is older than that of other peninsular territories, such as Navarre (1512). 
numerous protests by the Muslim/Arab community against the consequences of applying the provisions of the nationwide law to the special composition of the autonomous cities. The original law set more stringent conditions for the naturalisation process. Although most protests were peaceful, there was one violent incident which appears to have involved members of the Arab and the Hispanic communities and in which one person was shot dead and others were seriously wounded (Ramírez 1987). For the first time, secessionist claims were made by members of the Muslim/Arab community with the support of nationalist forces in Morocco. However, the protests against the application of the law were not backed by the Hispanic community, which instead demanded the application of the law in a massive demonstration commemorating the Constitution Day in Melilla (González 2008).

The regularisation of the status of the Moroccan nationals following the protests was the beginning of a process with a profound effect on the sociodemography of the two cities. Since then, the long-standing majority of the population of Spanish origin has been gradually shrinking. In recent times, due to family reunification and a high birth rate, the percentage of North African people is estimated to have reached $45 \%-50 \%$ of the population in both cities (Observatorio Andalusí 2016). The enlargement of these communities has had other significant impacts on the cities, such as urban segregation, economic inequalities, an exponential growth of Muslim parties, and a progressive political and cultural awakening.

\section{Claims for language recognition at national level}

The authorities have not conducted a systematic study of the sociolinguistic reality of the two cities, with data being especially weak in the case of Melilla. Even though the only sociolinguistic surveys available are limited in scope, $23 \%$ of the respondents to one survey (Fernández 2015) consider that Berber is the most used language in Melilla. In Ceuta, Arabic is estimated to be used by $26 \%$ of the population, and is the most commonly used language for $63 \%$ of the Muslim/Arab population (Rontomé et al. 2014). These languages are barely used by the Hispanic community; in contrast, the Arabic and Berber communities are mostly bilingual, with Spanish as a second language. Factors such as language prestige and social stratification, and the regime of official unilingualism and the resulting situation of diglossia affecting Berber and Arabic have led to a decline in their public use, especially among young generations. ${ }^{3}$

Attempts at a national level to gain co-official status for Tamazight and Dariya - oral varieties of the Berber language spoken in the Riff region and of

3. For a critical approach to the notion of diglossia in Ceuta, see Ready (2018). 
the Moroccan Arabic used in the northern area, respectively - have been unsuccessful. Giving their support to cultural and political stakeholders in Ceuta and Melilla, Catalan and Basque parties in the Spanish parliament proposed nonbinding laws (162/000195; 161/001466) in 2004 and 2006 which demanded the recognition of the identity and cultural features of the two North African cities, as well as stating the necessity for co-official status for the two languages; but these laws did not pass. Since these first refusals, cultural entrepreneurs in both cities and their representatives in the parliament have tempered their initial linguistic demands of co-officiality to more moderate forms of recognition, such as the presence of the languages in education - unlike the situation with the education systems of the autonomous communities of Spain, powers over education have not been transferred to autonomous cities. The most recent appeal at national level for the extension of language recognition to the autonomous territories was made in 2016 (161/ooo619).

In relation to this, it should be noted that the degree to which Arabic and Berber communities identify with claims made on their behalf about the longterm reproduction of these languages - not to mention the complex relationship between language and identity - has not yet been examined.

\section{Sources of legitimacy}

In general, the size and the concentration of the populations in Melilla and Ceuta who speak Tamazight and Dariya are the arguments put forward by those in favour of language recognition, particularly Muslim and left-wing parties. In contrast, those rejecting recognition use an argument based on the exogenous nature of these languages - that is, they claim an immigrant/national distinction. The endogenous or exogenous nature of Berber and Arabic is a point of contention between actors not only in the political realm but also from a legal perspective, which includes the possible implications in language policy-making.

At the local level, the Statute of Autonomy of Melilla includes a vague acknowledgement of the "cultural and linguistic plurality of Melillan people" (art. 5; my emphasis). ${ }^{4}$ In contrast, the Statute of Autonomy of Ceuta only alludes to the "cultural plurality of its people" (art. 5; my emphasis). This slight different in articulation was not without importance in terms of subsequent language recognition, as we shall see. At the national level, there are two potentially competing statements. On the one hand, the Spanish Constitution limits the consideration of co-official status to "other Spanish languages" (Section 3.2) that are explicitly acknowledged in the statutes of autonomy of the regions where they are spoken,

4. The translation here and elsewhere is that of the author. 
such as Basque, Catalan and Galician. On the other hand, the constitution states that "the different linguistic forms of Spain" (Section 3.3) will be protected as part of cultural patrimony. ${ }^{5}$

While it is not entirely clear that this latter provision includes languages such as Arabic and Berber, at supra-national level the Committee of Experts on the application of the European Charter for Regional or Minority Languages (ECRML) indicated in their initial monitoring cycle that Section 3.3 of the Spanish Constitution represents the charter's objectives and principles. Not only that, they described the constitutional provision as "one of the most exemplary formal recognitions of regional or minority languages as an expression of cultural wealth that can be found in Europe" (2005 Report: chapter 2.1.79) and they encouraged Spanish authorities to clarify the situation of both Arabic and Berber. In their response, Spanish authorities contended that the presence of both languages is the consequence of recent waves of immigration and, more specifically, the result of the naturalisation process begun in 1986 (2010 Report). This report by Spain illustrated this point with statistics showing that Maghrebi people in Ceuta constituted less than $10 \%$ of the total population in 1970; and a similar conclusion was provided for Melilla. Spanish authorities then concluded that Arabic and Berber cannot be considered as regional or minority languages of Spain. What the Spanish position aimed to rely on (albeit not pointing this out explicitly) is the ECRML's own statement that the charter's definition of regional or minority languages "does not include either dialects of the official language(s) of the State or the languages of migrants" (1992:art. 1a). This idea is more extensively explained by the Council of Europe's Explanatory Report to the ECRML: "the charter is not concerned with the phenomenon of non-European groups who have immigrated recently into Europe and acquired the nationality of a European State" (1992 Report: part I, art. 1.31).

Of course, Arabic and Berber have unequivocal historical ties to Ceuta and Melilla. However, the condition of being a long-settled linguistic minority is not necessarily met by the Arabic and Berber communities. Rather, their historical presence has been discontinuous. A long-term and complete language substitution seems to have taken place, as these territories were monoethnic communities for several centuries (Arteaga 2014:156). Until the late 19th century, the Mus$\mathrm{lim} /$ Arab population was non-existent, and it was still very small during the first

5. The liberal framework under discussion addresses the protection of languages as a means for endowing speakers with a context for choice and individual autonomy. However, this is at odds with the cultural heritage approach to languages traditionally used in Spanish legislation. 
third of the 2oth century (Meyer 2005). ${ }^{6}$ Nevertheless, perhaps surprisingly, in the third monitoring cycle in 2012, the Committee of Experts on the ECRML defined Berber as "the indigenous language of Melilla before the city became part of the Kingdom of Spain” (2012 Report: par. 20) - that is, more than 500 years ago - and encouraged authorities to recognise it as a traditional regional or minority language; there is no parallel statement about Arabic in Ceuta. Here, it must be noted that the Explanatory Report to the ECRML in 1992 clarified that their inclusion of a language as a historical regional, minority or traditionally used language of Europe covers only "languages which have been spoken over a long period in the State in question" (1992 Report: part I, art. 1.31; my emphasis). While the reasoning of the Committee of Experts in 2012 may thus be arguable, their ratification was important as it was a source of legitimacy that eventually led to the official recognition of Berber as a traditional language by the Assembly of Melilla, discussed in the following section.

In contrast to the situation of Melilla, the low level of interest by authorities in Ceuta $^{7}$ and, as noted above, the fact that its statute of autonomy refers to the city's plurality as only 'cultural' and does not include the term 'linguistic' resulted in the exclusion of any reference to Arabic in the lastest report of compliance with the ECRML by Spain (2016 Report), ${ }^{8}$ despite the insistence of the Committee of Experts on the ECRML in its successive reports. ${ }^{9}$ The latest report of the Committee of Experts includes a recommendation to initiate academic research into the situation of Arabic for purposes of clarification (2019 Report).

6. In my discussion below of the liberal framework, I therefore assume the immigrant character of Arabic and Berber in contemporary Spain. Although using a looser temporal criterion could lead to a different consideration of the nature of the current communities of Arabic and Berber speakers (e.g. Moscoso 2013), the empirical data given here shows that these groups are inevitably associated with a relatively recent immigration phenomenon. For that reason, I refer to them as groups of immigrant origin, regardless of whether they are naturalised Spanish citizens or not. What I do distinguish is first-generation immigrants from their descendants, for whom cultural rights should be conceptualised in a different way.

7. This contrasts with an important measure with political, social, and symbolic impact that has been taken in the domain of religion: in 2018, authorities included Eid al-Fitr, the day marking the end of Ramadan, as a school holiday in Ceuta. In 2010, the Muslim Eid al-Adha, the festival of sacrifice, was adopted as an official public holiday in both Ceuta and Melilla.

8. The lack of recognition has been claimed to be the result of 'Spanish linguistic nationalism' (Fernández 2015).

9. In fact, the issue of language became an obstacle to reaching agreement on an attempt to modify the Statute of Autonomy of Ceuta in 2007. The draft document recognised Dariya (Arabic), Hebrew, and Hindi as cultural heritage to be protected and promoted. 


\section{Deliberation and recognition}

In 2012, Melilla embarked on an unprecedented deliberative process to build what was presented as a sustainable, non-partisan, and non-religious model to manage cultural diversity. Despite the absence from the process of several actors of civil society and some political parties, public offices of both local and national administration and more than 40 associations, institutions, parties and cultural and religious communities took part in the various stages of the participatory process over two years (CICODE 2015). The contributions addressed a wide range of elements, including Islam and democracy, religious freedom, and cultural and language pluralism. Tamazight was at the heart of the proposals addressing pluralism. In 2014, the Assembly approved with wide support a declaration that embraces the principle of intercultural citizenship.

The resulting document, "Pacto Social por la Interculturalidad" (Melilla 2014), draws on a wide range of national and international policy, legal, and political documents, among which the "White Paper on Intercultural Dialogue" (Council of Europe 2008) is central. Short and explicit, the pact focuses on the intertwining of interculturality and various aspects of society, including dialogue, education, identity, coexistence, religion, gender equality, social cohesion, and language diversity. From a linguistic point of view, the explanatory memorandum of the pact asserts that "Melilla is essentially a Hispanic-Amazight city" (art. II-5, 14 ) and that Berber is the language of nearly half of the population, including $60 \%$ of pupils. ${ }^{10}$ As well as relying on the size and history of the community who speaks the language, the pact bases itself on the other legitimating factors of the Spanish Constitution, the Statute of Autonomy of Melilla, and the successive reports by the Committee of Experts on the ECRML discussed above.

Even more importantly, the enacting portion of the pact states that "the Assembly recognises Tamazight as a traditional language, which forms an inseparable part of the immaterial cultural heritage shared by all Melillans" (art. II-5, 14). In line with "the obligation to protect and safeguard Tamazight" (art. II-5, 14), the Assembly commits to take the necessary measures to implement the ECRML's principles and objectives; for instance, the administration will ensure that any Melillan can learn Tamazight. In sum, Berber is given status on the level of other recognised Spanish languages with no official bilingual regimes, such as Asturian and Aragonese and, at least partially, language claims thus became rights. It is noteworthy that the recognition of Berber was inscribed within a wider framework of

10. It is worth noting that the current unilingual educational model in both Melilla and Ceuta has as a consequence a high degree of failure at school (see Sánchez 2010). 
interculturalism, though the latter is critical of rights-based approaches to citizenship (Zapata-Barrero 2016).

\section{Challenges to normative approaches to multiculturalism and minority rights: Applications and problems}

In this section, I move on to the analysis of the foundations of liberal theories of multiculturalism to get a normative insight into the dominant national/immigrant analytical categories. I also outline the mismatch between the implications of this discrete approach and the contextual factors of the case study.

The national versus immigrant minority distinction

The first scholar who addressed the discrete approach or "demarcation line between immigrants and indigenous groups" was Heinz Kloss (1971:252). Despite being a broad-brush approach to immigrant groups' language rights, the significance of his work is that it established the theoretical foundations for a widely accepted dichotomy between toleration- and promotion-oriented rights. His arguments follow a transaction logic, which implies that immigrant groups waive any claim to minority rights. Consequently, only toleration-oriented rights apply to immigrant languages.

Notwithstanding their more refined rationale, prominent liberal theorists, such as Kymlicka and Patten, have stuck to Kloss's dichotomy. In his attempt to reconcile liberalism with group rights, Kymlicka (1995) develops the well-known theoretical account of a societal culture based on the Rawlsian notion of primary good, a membership-based cultural context necessary for meaningful choice and individual autonomy. With this as the background, he distinguishes between multinational and polyethnic societies as showing distinct forms of cultural pluralism: whereas a multinational state is composed of national minorities involuntarily incorporated into it, immigrant minorities have voluntarily accepted to become part of a new country and aim to integrate and become full members of the larger society. This acceptance framework is then reflected in two different kinds of group-differentiated rights: self-government (political autonomy or territorial jurisdiction) for groups in multinational states, and polyethnic rights (integration policies) for immigrant minorities. Unlike national minorities, the alleged voluntariness of immigrants' presence in a new country implies that they (voluntarily) waived their national membership. As immigrants then have no claim to national self-government, they can only opt for some other level of representation and recognition. In short, immigrants' free choice to leave 
their own culture presupposes the relinquishment of any cultural and linguistic claims beyond the accommodation rights assigned by liberal democracies. These 'norm-and-accommodation rights' are about facilitating communication in the predominant language. They comprise special accommodations for people who lack sufficient proficiency in the language of public communication and include, for instance, the provision of interpreters, bilingual staff, and intensive language programmes (Kymlicka \& Patten 2003b: 8).

It is worth delving into Kymlicka's framework to gain a clearer picture of the possible implications for the ongoing language claims in Ceuta and Melilla. The core feature of immigrant group rights in this framework is their integrative nature. Kymlicka (1995:63-67) argues that, unlike national minorities, immigrant demands are for inclusion into the mainstream national culture. Since, for him, empirical evidence does not indicate immigrant groups' interest in seeking national self-government rights in order to recreate their own societal culture, their demands basically consist of, firstly, self-identification and self-expression and, secondly, visibility and recognition as a full members of the larger society. To that end, these group rights seek to "modify the institutions and laws of the mainstream society to make them more accommodating of cultural differences" (Kymlicka 1995:11). In order to promote integration, dominant institutions, for their part, should show adaptability to cultural differences as "[i]mmigrants can rightfully insist on maintaining some of their heritage" (1995:97). Importantly, polyethnic rights may also include public funding for cultural practices.

So, where do the more general attempts to gain official recognition in the Spanish enclaves lie in Kymlicka's account? It is important to recall that the actual aim of this model is how to best accommodate linguistic differences within a given linguistically established society:

[T]here are many ways that special efforts should be made to accommodate the cultural differences of immigrants. But all of these measures take the form of adapting the institutions and practices of the mainstream society so as to accommodate ethnic differences, not of setting up a separate societal culture based on the immigrants' mother tongue.

(Kymlicka 1995: 97)

Now, whereas the examples of officially bilingual autonomous communities in Spain demonstrate that adopting an official bilingual regime within one territory or receiving some kind of official language recognition is not a base for establishing a separate societal culture, conferring official status does involve the promotion of an identity and intrinsic dimension of the language (Kymlicka \& Patten 2003b). This equal level of recognition between languages, then, goes beyond the sorts of accommodation benefits to which immigrants are entitled, which fundamentally centre around individuals having the ability to communicate with the 
administrative organs of the state. In fact, Kymlicka (1995:112) only refers to official languages in relation to national minorities: the official status is an opportunity to maintain the distinctive culture of national groups. The adoption of a measure such as official status for an immigrant-origin language would not be understood as accommodative in nature or as promoting integration, which are Kymlicka's conditions for immigrant-oriented rights.

Following this reasoning, the attempt in the Spanish parliament in 2004 to confer official status on Berber and Arabic in the autonomous cities seems to go beyond what Kymlicka's liberal theory requires. But what is apparent here is that the scope of this parliamentary initiative contrasts with Kymlicka's (1995:179) general assumption that immigrants' demands are modest (see also Kymlicka \& Patten 2003b:5-6).

Kymlicka (1995:25) acknowledges the possibility of a sound, empirically based alternative to his consent theory. He recognises that some cultural groups (e.g. refugees and descendants of guest workers) might not fit neatly into either the national or the immigrant category. What is more, he launches - and then rejects - a counter-argument to his conceptualisation of a dichotomy between minority groups, based on an empirical observation:

Given these hard cases and grey areas, it might seem misguided to try to develop a theory of minority rights which attaches any weight to the distinction between ethnic groups and national minorities. Perhaps we should instead think of all these groups as falling on a continuum. But there are many clear cases of voluntary immigrants and national minorities.

In his revisiting of Kymlicka's theory, Patten (2003, 2014) acknowledges its weaknesses and opts for a more elaborate defence of the distinction between groups, looking for other principles of moral authority - namely, voluntariness, alienability and recipient's permission - to satisfy the main objections raised by critics. ${ }^{11}$ Unlike Kymlicka's context of choice, Patten builds his account around a fresh approach to the conception of liberal neutrality. States have the obligation to be neutral to various conceptions of the good. In order to discharge their responsibility in this sense, Patten defends a neutrality of treatment, which means equally accommodating those various conceptions of the good (including cultural practices) by granting fair treatment and self-determination to all citizens. His understanding of liberal neutrality can entail an equal recognition of national majority

11. Critics of Kymlicka's voluntary argument have appropriately questioned the consistency of the assumption that immigrants readily waive their rights to their original societal culture, on the basis that Kymlicka himself argues that it is a fundamental and meaningful primary good for people - see, for example, Weinstock (1999) and Carens (2000). 
and minority cultures and their access to public institutions, as well as the protection and support of minority cultural rights.

On the specific issue of immigrants' cultural rights, the morally relevant distinction, Patten argues, is not to be found in a dichotomy between immigrants and national minorities but in the asymmetry between newcomers and established members of the receiving society. The result is a sophisticated reformulation of the voluntary acceptance theory that relies on principles such as legitimacy, reasonableness, and choice: first, in order to safeguard the receiving society's interests, the state can legitimately require immigrants to forgo a selection of rights as a condition of admission if the terms for being accepted are reasonable. Reasonable terms include, for instance, the presumed value of the benefit of acceptance to the individual. The capacity of choice remains effective as options are determined by how reasonable the terms of agreement to obtain immigrant status are. Second, within the existing rights, toleration and accommodation rights are inalienable but waiving non-accommodation cultural and linguistic rights is an acceptable burden and, therefore, a reasonable requirement. This is because immigrants are entitled to accommodation rights, which comprise integration policies that enable them to access the dominant public language in the receiving society. This being so, restricting the right of access to a full range of options in their own language is a legitimate claim as it is not necessary for immigrants to recreate their original culture in the receiving society. Third, the asymmetry between established groups and newcomers is justified for two reasons: the situational argument or primacy of established practices and institutions over the claims of immigrants; and the perspectival argument or reasonable exercise of partiality by national citizens when they opt for their own objects of attachment instead of for the claims of newcomers. ${ }^{12}$ Patten's conclusion is that it is reasonable and permissible to prioritise the claims of national groups over those of immigrants. Given this, the implications of Patten's approach for language claims in Ceuta and Melilla remain the same as in Kymlicka's original theory.

Patten acknowledges the possibility that some states could extend language rights to other groups, including immigrant groups, but argues that liberal principles do not require them to do so. Similar to Kymlicka, Patten (2003:181-183, 2014:272-273) recognises that "the general criteria approach may turn out to be the best we can do in allocating minority rights", and he dismisses a contextual approach based on contingent criteria, such as the size of the group or its concentration, as these sorts of accounts have "weaknesses" "counterintuitive implications",

12. Some authors note an inconsistency in this argument as Patten defends the premise that principles (and not the decision-making authority) should guide a legitimate policy but does not apply it in the case of the cultural rights of immigrants (see Stojanović, 2017: 106). 
and "a radical edge". Instead, he opts for a principle-based approach intended to be persuasive in most situations.

Patten's appeal to the notions of legitimacy and reasonableness to support the distinction between the groups presumably derives from assumptions about the way that states function towards immigrant groups, not from a value system separate from practice. In fact, when it comes to the concept of reasonableness, if the temptation to bend theories around dominant political realities is avoided (Choudhry 2002:78), then a variety of reasonable alternative responses to language claims could be found. For instance, Carens (2000:84) appeals to reasonable language policies for linguistic minorities and argues that his conceptualisation of justice as even-handedness "leaves considerable scope for differing views as to how the competing interests should be accommodated", even including the officialisation of immigrant languages. Likewise, in May's (2017) account, reasonableness is construed as a provision of some level of state services and activity in the public domain, such as language protection, where there are sufficient numbers of speakers of an immigrant language.

\section{Descendants of groups of immigrant origin}

Overall, according to the discrete approach outlined above, the only language rights that first-generation immigrant speakers of Berber or Arabic could expect to be assigned by public institutions in Ceuta and Melilla are transitional accommodation rights. For instance, since Spanish is the language of public communication between institutions and individuals, the application of the accommodation model would consist of the provision of services for people with insufficient proficiency in Spanish: interpreters, bilingual staff, immersion programmes in Spanish, and so on (Kymlicka \& Patten 2003b). Likewise, the implementation of the heritage language in education for maintenance purposes would be subject to the discretion of the competent authorities. Nevertheless, the discrete approach would imply, as a general rule, education only through Spanish since one of the cultural rights to be renounced by naturalised foreign-born people is their own first language as a medium of instruction for their children (Patten 2014:276), which has been in fact the system in the two North African cities.

The sole possibility within the discrete approach for leaving behind the accommodation model and plunging into promotion rights involves the descendants of naturalised newcomers and immigrant children. Unlike the first generation of adult immigrants naturalised in Ceuta and Melilla in 1986, the second generation are not to be considered as immigrants, but as national citizens with a full set of cultural rights, including promotion rights. In this sense, Patten relies, perhaps excessively, on the instrumentally based assumption that an education 
through the national or majority language received by bilingual descendants of an immigrant minority group would make them choose the non-heritage language as the normal means of communication with public institutions.

While there may be empirical evidence that this is the situation in most cases throughout the world, the identitarian dimension of language choice or language use as a marker of ethnic identity is a factor not to be prematurely dismissed in particular cases (Bauböck 1996:225). Indeed, Arabic is the language with which $23 \%$ of the population in Ceuta identifies (Rontomé et al. 2014) and the attitude of secondary school Muslim/Arab students in both cities towards the use of Arabic and Berber is generally positive (Fernández 2016). Let us consider the hypothetical, but entirely possible, situation in which a relevant number of second-generation bilingual speakers or people who immigrated when they were children make the decision to use Berber and Arabic with the administration for identity-based reasons. Let us also assume that these nationals comply with the condition laid down by Patten (2014:276): "an enduring attachment to the culture of their parents and grandparents". In this case and if numbers warrant, would they be in a position to expect to be offered services in those languages? Or to put it another way, would the normative foundations of the discrete approach sustain such a claim?

Patten (2014:276) does not explore this situation and only suggests in passing that "the account will eventually have to say something about descendants of immigrants". He concludes that an analysis and evaluation of the cultural and language interests, claims and rights of descendants would be necessary. It would seem, then, that despite the lack of a fully elaborated formulation in the discrete approach, the response to the preceding questions would be affirmative, at least as long as reasons other than the instrumental dimension of language - namely identity or constitutive reasons - are among those that motivate our hypothetical Spanish-Arabic/Berber bilingual speakers to choose to use their home language with public institutions. Assuming that this is the case, it is of great importance, since there is no obvious reason not to conclude that this would also have the implication of affecting other services in the public sphere, such as language provision in education, public media, signage or any other kind of public service. Again, if the previous arguments are correct, we would have a situation very similar to the maximalist claims made by language activists demanding official status for Berber and Arabic, except that it would only pertain to the subsequent generations; in other words, there would be an effective national-immigrant bilingual regime in Ceuta and Melilla promoted by descendants of naturalised immigrants. 


\section{Lessons from the case study: A contextual approach}

Liberal states are reluctant to open up the Pandora's box (Weinstock 1999) of granting extensive cultural rights, if any, to non-autochthonous groups. Many people find the dichotomy between immigrant minority groups and national minority groups an intuitive distinction. The discrete approach to minority group rights conforms to the premises of current political practice and dominant policymaking. However, what justice requires may not coincide with existing norms (Modood \& Thompson 2018). The discrete approach fails to deal with the distinctive features that have been discussed here that make Ceuta and Melilla a 'tricky' or 'in-between' case, one that does not fit the analytical categories within this approach. One could argue that these two North African cities represent an exception, a discordant reality in which the empirical evidence makes the case morally ambiguous. And it must be admitted that not many political jurisdictions meet the geographical, sociocultural and political features of these Spanish cities. ${ }^{13}$

Let me summarise these features. First, historically, the cities both comply with the condition of formative territories, which is essential for the successful implementation of certain rights (Gans 2001). Second, the estimates of sociodemographic dynamics suggest that, for both cities, the population with an origin other than the Iberian peninsula may comprise a clear majority in the near future (Rontomé 2012). Third, descendants of the first generation of immigrants are among those claiming to bear cultural rights for identity reasons.

But the point I wish to make is not confined to a mere description and explanation of the uniqueness of the facts in a particular case. I concur with Levy's (2007) view that normative political theories of multiculturalism should attempt to resolve disputes over cultural claims, not merely report on their terms. What I am suggesting with my critique of the discrete approach is a contextualist ${ }^{14}$ claim according to which context determines the implications of principles for particular cases. Contextualism is not principle free but principle- and contextdependent. To be specific, my position is similar to what Lægaard $(2015,2019)$ calls applicatory contextualism, a widely shared view according to which arguments for normative judgments require both normative and empirical premises. It is in the interaction between contextual facts and principles that specific conclusions about the requirements of justice are generated (Modood \& Thompson

13. Similar exceptions would include the Spanish- and Russian-speaking groups in some parts of the United States and the Baltic states respectively.

14. Lægaard (2019:954) defines contextualism in normative political theory as the "family of views holding that factual claims about the context of a case are part of the justification of normative political judgments about this case". 
2018). Following this rationale, it does not seem morally convincing that Patten's non-contingent theory based on group-differentiated rights and grounded on principles such as legitimacy or reasonableness denies the language claims of large numbers of citizens in Ceuta and Melilla only because they do not have the inherent rights that national minorities do. The consideration of these principles along with the contextual elements of our case may well lead to a policy outcome other than the transitional accommodation rights that are proposed by the discrete approach.

As importantly, the contextual approach comprises less-than-universal levels of generality. Much of the political theory of multiculturalism is of the contextual variety (Kukathas 2004), in the sense that its arguments and theories only arise in certain contexts under specific conditions. However, when it comes to immigrant rights, Kymlicka's and Patten's theories are all-encompassing, that is they are intended to apply to all cases. They opt for 'basic reasons of principle' or justificatory principles that are meant to have a quasi-universal level of generality and validity, and as result, are not sufficiently sensitive to contextual elements and circumstances such as the ones featured in Ceuta and Melilla. Simply put, these particular contexts show the lack of applicability of their theories in 'non-standard cases' of language rights of groups of immigrant origin. Hence, my line of criticism does not necessarily question the overall plausibility of liberal theories of multiculturalism but concentrates on the fact that these accounts are justified on principled grounds that are not derived from or do not sufficiently interact with specific cases $;{ }^{15}$ in particular, cases in which the rigid national/immigrant analytical categories used by these authors do not apply. The fact that Kymlicka's and Patten's theories require actual cases to fit the simplifying and idealising assumptions made for the authors' analytical argument is what is troubling.

Another important point is that the contextual approach breaks away from the top-down nature of some political theories (Lægaard 2015) and leaves room for the demands of specific contexts, political dialogue, and democratic practices to inform theory in the normative analysis of policy and institutional arrangements. The 'Melillan solution', treating Berber as a traditional language and part of the cultural heritage of the city, is the result of a process of contextual interpretation. It

15. Patten (2014:231) himself argues for such an interaction with cases, for instance, in his defence of a hybrid approach to language rights for national groups, which involves the nationbuilding and language preservation models and his concept of equal recognition. He endorses a personality principle over a territoriality principle but admits that his approach has "distinctive policy implications". He concludes that "adopting that principle [the territoriality principle] may still be the best overall approach, under some empirical conditions, but under other conditions the local majority language will have to limit its dominion to leave some room for minority languages". 
presents a locally based and perhaps ineluctable solution to a specific real-world problem of conflicting interpretations of groups' rights. Rather than being based on an "all or nothing" stark dichotomy, the differences of cultural minorities are situated along a continuum that permits them to be thought of as a matter of degree and not of type or nature (Young 1997). Put another way, the Melillan example represents a normative-based response to a particular set of facts - the size, concentration and history of the community and the nature of the language claims ${ }^{16}$ where there is a scale of priorities and an allowance for adaptive changes and a progressive implementation of language policies.

So what are the implications of theory being informed by situated practices, which is what I am arguing for? Let's consider the principle of legitimacy for the recognition of Berber as a traditional language of Melilla. In a period in which citizens' participation and trust in democratic life is in decline (Parvin 2018), the city of Melilla was able to build a process of social deliberation by promoting citizens' involvement in the governance of diversity. As a result, not only were the principles of interculturality supported by general agreement but a new source of legitimacy for language claims was devised, one that involves recognition across difference through deliberation. In other words, a context-based principle of legitimacy emerged. Unlike the claim of theories of deliberation, the deliberative practices and political dialogue from which legitimacy arose in Melilla did not occur in an abstract or contextless form (Parekh 2006). Instead, they took place in a society with a particular history, social and political configuration and set of public values as well as through a situated process with its own specific characteristics. Examples of these particularities are some areas of the participatory process, which were less satisfactory than expected, in particular the representation of some relevant actors, the degree of involvement of some participants, and the decline in contribution rates in the second stage of the process (CICODE 2015). Although the legitimacy of the process is not under scrutiny, as the political representatives in the Assembly ratified the resulting document by majority rule, legitimacy is also to be sought in the procedures of participation and in the deliberations of the actors subject to a collective decision (Dryzek \& Niemeyer 2006). In addition, insufficient consultation and a lack of social consensus around the adoption and implementation of certain language policies with symbolic significance might provoke division (Erdocia 2019). So the issues that were encountered reveal some limits in the deliberative decision-making and participatory process in Melilla. This raises questions about the actual level of consensus achieved and,

16. Other criteria posited by Rubio-Marín (2003) are free individual and collective choice as the basis for minority language maintenance; threat to autochthonous linguistic groups; and the level of impact on the receiving society. 
ultimately, the notion of consensus itself in societies with a significant degree of pluralism. In summary, these practices indicate that legitimacy originates under specific circumstances. We can conclude therefore that the way in which practices in real cases inform theory may be less than an ideal process, which can be argued to be an objection to the contextual approach.

In any case, the example of Melilla shows that the official recognition of a language of immigrant origin should not necessarily be seen as out of touch with reality and branded as utopian, or at least politically imprudent and counterproductive in practice. To misquote Patten, this case is perhaps "the most we can do in allocating minority rights" but the outcome is still reasonable and realistic. This case shows that such an enquiry is not an assessment in the light of the highest possible ideals in relation to the ethics of migration or an "idealistic approach to morality" in the terms of Carens (1997:167) but a realistic assessment.

Having said that, there are two elements found in the context analysed here which are indispensable prerequisites for the adoption of a solution of this type: a flexible language rights-oriented legal framework, which made possible the sometimes confusing feedback loops between the Committee of Experts on the ECRML and the periodical reports by the Spanish authorities; and political will and consent, without which language claims simply fall on deaf institutional ears, as in Ceuta. What this implies methodologically is that, first, there are practical constraints on certain courses of action and, secondly, feasibility constraints need to be borne in mind in our moral reflections, at least if we want them to lead to practical moral choices, policy change, and impact in public life (Modood and Thompson 2018).

Take the issue of political will and consent. The strategies of the major national-level parties traditionally represented in Ceuta and Melilla (the Partido Popular and the Partido Socialista) have resulted in different stances towards the accommodation of language claims in the two cities: apparent indifference in Ceuta but agreed official recognition emerging from the participatory politics in Melilla. At the national level, both these parties have always rejected initiatives aimed at the recognition of Arabic and Berber. This can be described as an ideology of pragmatism' or policy-making guided by considerations of what is practical or beneficial rather than by matters of principle (Wee 2011). Thereby, what the case of the autonomous cities also reflects is that support for language claims in the political arena is not a straightforward consequence of a given linguistic reality as much as the result of a changing political calculation of opportunity and costs. The upshot is that a society's operative principles in public life are of necessity dependent on the contingencies of the political world. The consequences are that, on the one hand, politics can give rise to significant discrepancies in the policy outcomes of similar contexts, such in our case study; while on the other hand, the 
dependence on politics can be objected to both by theorists committed to respecting the boundaries between political theory and ordinary politics and by those multiculturalist theorists who seek an indisputable basis for liberal ideals.

\section{Conclusion}

The contextual facts and historical circumstances of Melilla and Ceuta, the two Spanish cities in North Africa, are challenging for the dominant normative approaches to minority rights. As argued throughout this article, theories of liberal multiculturalism based on analytical categories distinguishing between nationals and immigrants fall short when it comes to these cities because the theories are too frugal with respect to the claims for language recognition by Arabicand Berber-speaking communities. Dismissing any consideration of criteria such as the size, concentration and history of communities and the nature of their language claims is hardly an option for a normative judgement about this case. I have contended that contextualism is better suited to conceptualise the recognition of language rights. This approach is not only about contingent criteria determining a certain course of action for policy change but requires normative arguments in the form of context-based principles. Contextualism also allows for the appreciation of political processes and democratic procedures as a means of resolving struggles over recognition of immigrant cultures.

In closing, group rights conferred on national minorities are a relatively recent accomplishment in many states. In fact, normative claims preceded what later became more widespread practice in Western democracies and the lack of the latter did not affect the normative validity of the former. More recently, Kraus (2008:100) contended that

there is increasing empirical evidence that the changes of the socio-linguistic constellation brought about by the 'new' minorities will have a substantial impact on the democratic fabric of Western polities. In the long run, they might well lead to modifying the normative premises upon which minority policies were based until now.

Even though a decade later, in a more adverse Western political scenario, there are weighty reasons (nationalism, populism, nativism, anti-immigration, etc.) to be more sceptical about the policy expectations of this statement, the particular case of Melilla illustrates the possibility of such a change being realised. The contextualist approach may give rise to normative judgements about other rapidly changing transnational cases that go in the same direction. 


\section{Funding}

This work was supported by the fund of the Faculty Conference Travel Scheme, 2017-2018, Dublin City University, awarded to Iker Erdocia.

\section{References}

Application of the ECRML in Spain. Initial Monitoring Cycle (2005) https://www.coe.int/t /dg4/education/minlang/Report/EvaluationReports/SpainECRML1_en.pdf (accessed o1/o7/19).

Application of the ECRML in Spain. Third Monitoring Cycle (2012). https://rm.coe.int /168o6dba6b (accessed o1/o7/19).

Application of the ECRML in Spain. Fourth Monitoring Cycle (2016). https://rm.coe.int /16806fo658 (accessed 01/o7/19).

Application of the ECRML in Spain. Fifth Monitoring Cycle (2019). https://search.coe.int/cm /Pages/result_details.aspx?ObjectId=0900001680993e63 (accessed 19/02/20).

Arteaga, F. (2014). España Mirando al Sur: del Mediterráneo al Sahel. Informe del Real Instituto Elcano 18.

Bauböck, R. (1996). Cultural Minority Rights for Immigrants. International Migration Review, 30 (1): 203-250. https://doi.org/10.2307/2547468

Carens, J. (200o). Culture, Citizenship, and Community: A Contextual Exploration of Justice as Evenhandedness. Oxford: Oxford University Press. https://doi.org/10.1093/0198297688.001.0001

Choudhry, S. (2002). National Minorities and Ethnic Immigrants: Liberalism's Political Sociology. Journal of Political Philosophy, 10 (1): 54-78. https://doi.org/10.1111/1467-9760.00142

CICODE. (2015). Construir Ciudadanía Intercultural. Granada: GEEPE.

Council of Europe. (2008). White Paper on Intercultural Dialogue: Living Together as Equals in Dignity. Strasbourg: Council of Europe.

De Schutter, H. (2007). Language Policy and Political Philosophy. On the Emerging Linguistic Justice Debate. Language Problems \& Language Planning, 31 (1): 1-23. https://doi.org/10.1075//plp.31.1.02des

ECRML (1992). https://rm.coe.int/1680o7bf4b (accessed o1/o7/19).

Erdocia, I. (2019). Medium of Instruction Ideologies: Accommodation of Multilingualism in the Bilingual Regime of Navarre. Current Issues in Language Planning, 19 (4): 1-25. https://doi.org/10.1080/14664208.2018.1503457

Explanatory Report to the ECRML (1992). https://rm.coe.int/1680ocb5e5 (accessed 01/o7/19).

Fernández, A. (2015). Repensar las Fronteras Lingüísticas del Territorio Español: Melilla, entre Mosaico Sociológico y Paradigma Lingüístico. Estudios de Lingüística Universidad de Alicante, 29: 105-126. https://doi.org/10.14198/ELUA2015.29.05

Fernández, A. (2016). Nacionalismo y Representaciones Lingüísticas en Ceuta y en Melilla. Revista de Filología Románica, 33 (1): 23-46. https://doi.org/10.5209/RFRM.55230

Gans, C. (2001). Historical Rights: The Evaluation of Nationalist Claims to Sovereignty. Political Theory, 29 (1): 58-79. https://doi.org/10.1177/0090591701029001004 
González, C. (2008). Los Frenos al Pluralismo Cultural en Territorios de Soberanía Discutida: Los Casos de Ceuta y Melilla. Revista de Estudios Políticos, 140: 135-161.

INE. (1987). Estudio Estadístico de las Comunidades Musulmanas de Ceuta y Melilla. Madrid: INE.

Kloss, H. (1971). Language Rights of Immigrant Groups. International Migration Review, 5 (2): 250-268. https://doi.org/10.1177/019791837100500208

Kraus, P. (2008). A Union of Diversity: Language, Identity and Polity-Building in Europe. New York: Cambridge University Press. https://doi.org/10.1017/СBO9780511491993

Kukathas, C. (2004). Contextualism Reconsidered: Some Skeptical Reflections. Ethical Theory and Moral Practice, 7 (2): 215-225. https://doi.org/10.1023/B:ETTA.0000032808.92466.f5

Kymlicka, W. (1995). Multicultural Citizenship. New York: Oxford University Press.

Kymlicka, W., \& A. Patten (Eds.). (2003a). Language Rights and Political Theory. Oxford: Oxford University Press. https://doi.org/10.1017/S0267190503000163

Kymlicka, W., \& A. Patten. (2003b). Language Rights and Political Theory. Annual Review of Applied Linguistics, 23: 3-21. https://doi.org/10.1017/S0267190503000163

Lægaard, S. (2015). Multiculturalism and Contextualism: How is Context Relevant for Political Theory? European Journal of Political Theory, 14 (3): 259-276. https://doi.org/10.1177/1474885114562975

Lægaard, S. (2019). Contextualism in Normative Political Theory and the Problem of Critical Distance. Ethical Theory and Moral Practice, 22 (4): 953-970. https://doi.org/10.1007/s10677-019-10026-6

Léger, R., \& H. Levis. (2017). Normative Political Theory's Contribution to Language Policy Research. Journal of Multilingual and Multicultural Development, 38 (7): 577-583. https://doi.org/10.1080/01434632.2016.1192177

Levy, J. (2007). Contextualism, Constitutionalism, and Modus Vivendi. In A.S. Laden \& D. Owen (Eds.), Multiculturalism and Political Theory (pp. 173-197). Cambridge: Cambridge University Press.

May, S. (2017). National and Ethnic Minorities: Language Rights and Recognition. In S. Canagarajah (Ed.), The Routledge Handbook of Migration and Language (pp. 149-167). New York: Routledge. https://doi.org/10.4324/9781315754512-9

Melilla (2014). Pacto Social por la Interculturalidad. http://www.melilla.es/melillaportal /RecursosWeb/DOCUMENTOS/1/o_11857_1.pdf (accessed 01/07/19).

Meyer, F. (2005). Die Städte der Vier Kulturen: Eine Geographie der Zugehörigkeit und Ausgrenzung am Beispiel von Ceuta und Melilla (Spanien/Nordafrika). Stuttgart: Franz Steiner Verlag.

Modood, T., \& S. Thompson. (2018). Revisiting Contextualism in Political Theory: Putting Principles into Context. Res Publica, 24 (3): 339-357. https://doi.org/10.1007/s11158-017-9358-1

Moscoso, F. (2013). El Árabe de Ceuta. Argumentos para su Cooficialidad. In P. Santillán, L.M. Pérez, \& F. Moscoso (Eds.), Árabe Marroquí: De la Oralidad a la Enseñanza (pp. 95-124). Cuenca: Universidad de Castilla-La Mancha.

Oakes, L. (2017). Normative Language Policy and Minority Language Rights: Rethinking the Case of Regional Languages in France. Language Policy, 16 (4): 365-384. https://doi.org/10.1007/s10993-016-9411-5

Oakes, L. \& Y. Peled. (2018). Normative Language Policy: Ethics, Politics, Principles. Cambridge: Cambridge University Press. 
Observatorio Andalusí. (2016). Estudio Demográfico de la Población Musulmana. Exploración Estadística del Censo de Ciudadanos Musulmanes en España Referido a Fecha 31/12/2015. Madrid: UCIDE.

Osborn, A. (2002), August 27). Arabic: A language for Belgium? The Guardian. Retrieved from https://www.theguardian.com

Parekh, B. (2006). Rethinking Multiculturalism: Cultural Diversity and Political Theory. Basingstoke: Palgrave. https://doi.org/10.1007/978-0-230-20425-6

Parvin, P. (2018). Democracy without Participation: A New Politics for a Disengaged Era. Res Publica, 24 (1): 31-52. https://doi.org/10.1007/s11158-017-9382-1

Patten, A. (2003). Can the Immigrant/National Minority Dichotomy be Defended? In

S. Macedo, \& A. Buchanan (Eds.), Secession and Self-Determination (pp. 174-189). New York: New York University Press.

Patten, A. (2014). Equal Recognition: The Moral Foundations of Minority Rights. New Jersey: Princeton University Press.

Peled, Y. (2014). Normative Language Policy: Interface and Interferences. Language Policy, 13 (4): 301-315. https://doi.org/10.1007/s10993-014-9325-z

Pidd, H. (2011), February 28). Germany Hits Back after Turkish PM Tells Immigrants to Resist Assimilation. The Guardian. Retrieved from https://www.theguardian.com

Ramírez, S. (1987), February 3). Estrecha Vigilancia Policial en Melilla para Prevenir Nuevos Brotes de Violencia. ABC. Retrieved from https://www.abc.es

Ready, C. (2018). Maintaining the Status Quo. Diglossia and the Case of Arabic Language Policy in Ceuta. Language Problems and Language Planning, 42: 173-195. https://doi.org/10.1075/Iplp.ooo18.rea

Ricento, T., Y. Peled, \& P. Ives (Eds.). (2015). Language Policy and Political Theory: Building Bridges, Assessing Breaches. New York: Springer. https://doi.org/10.1007/978-3-319-15084-o

Rontomé, C. (2012). Ceuta, Convivencia y Conflicto en una Sociedad Multiétnica. Ceuta: UNED.

Rontomé, C., J.M. Cantón Gálvez, \& I. Lázaro. (2014). Los Usos Lingüísticos de la Poblacion de Ceuta. Ceuta: IEC.

Rubio-Marín, R. (2003). Exploring the Boundaries of Language Rights: Insiders, Newcomers, and Natives. In S. Macedo, \& A. Buchanan (Eds), Secession and Self-Determination (pp. 136-174). New York: New York University Press.

Sánchez, S. (2010). El Abandono Escolar Temprano en las Ciudades de Ceuta y Melilla. Madrid: Ministerio de Educación.

Stojanović, N. (2017). Normative Political Theory, Democratic Politics and Minority Rights. Critical Review of International Social and Political Philosophy, 20 (1): 101-113. https://doi.org/10.1080/13698230.2016.1253168

Third Periodical Report of Spain's Compliance with the ECRML 2006-2009. (2010). http:// www.coe.int/t/dg4/education/minlang/Report/PeriodicalReports/SpainPR3_en.pdf (accessed 01/07/19).

Van Parijs, P. (2011). Linguistic Justice for Europe and for the World. Oxford: Oxford University Press. https://doi.org/10.1093/acprof:osobl/9780199208876.001.0001

Wee, L. (2011). Language without Rights. Oxford: Oxford University Press. https://doi.org/10.1093/acprof:0so/9780199737437.001.0001

Weinstock, D. (1999). Le Probleme de la Boîte de Pandore. In M. Seymour (Ed.), Nationalité, Citoyenneté et Solidarité (pp. 17-40). Montreal: Editions Liber. 
Young, I. M. (1997). A Multicultural Continuum: A Critique of Will Kymlicka's Ethnic-Nation Dichotomy. Constellations, 4 (1): 48-53. https://doi.org/10.1111/1467-8675.00035

Zapata-Barrero, R. (2016). Theorising Intercultural Citizenship. In N. Meer, T. Modood, \& R. Zapata-Barrero (Eds), Multiculturalism and Interculturalism: Debating the Dividing Lines (pp. 53-76). Edinburgh: Edinburgh University Press. https://doi.org/10.3366/edinburgh/9781474407083.003.0003

\section{Resumen}

En este artículo, mi objetivo es analizar los derechos lingüísticos en relación a los grupos de origen inmigrante. Las democracias liberales son reacias a considerar a los grupos inmigrantes como sujetos que pueden optar a los mismos derechos lingüísticos y culturales que las minorías nacionales. Sin embargo, el actual aumento en el flujo de inmigración está configurando nuevas correlaciones lingüísticas y culturales dentro de los países que provocan reacciones que ponen en duda una concepción estática de los derechos lingüísticos. Tomando como referencia las teorías del multiculturalismo liberal, analizo el caso de las reivindicaciones por el reconocimiento lingüístico en las ciudades autónomas españolas de Ceuta y Melilla, así como sus implicaciones normativas. En estos territorios, factores como el tamaño, la concentración y los lazos históricos de las comunidades lingüísticas del árabe y del bereber cuestionan los posicionamientos convencionales sobre los derechos de las minorías basados en la distinción entre grupos nacionales e inmigrantes. Desarrollo la idea de que este tipo de posicionamientos no responde adecuadamente a las demandas lingüísticas en estas dos ciudades y que un enfoque contextual es más adecuado para conceptualizar el reconocimiento de los derechos lingüísticos.

\section{Resumo}

En ĉi tiu artikolo mi celas analizi lingvajn rajtojn rilate al grupoj de enmigrinta origino. Liberalaj demokratioj hezitas doni al enmigrintaj grupoj la samajn lingvajn kaj kulturajn rajtojn, kiujn ĝas naciaj malplimultoj. Tamen la tendenco al kreskantaj niveloj de enmigrado donas formon al novaj kulturaj kaj lingvaj interrilatoj ene de teritoriaj limoj, kiuj instigas respondojn, kiuj problemigas fiksan koncepton pri lingvaj rajtoj. Uzante teoriojn de liberala multkultureco, mi ekzamenas la kazon de asertoj pri lingva rekono en la hispanaj aŭtonomaj urboj Ceŭto kaj Melilo kaj ĝiajn normigajn implicojn. En ĉi tiuj teritorioj, faktoroj kiel grandeco, koncentriĝo kaj la historiaj ligoj de arabaj kaj berberlingvaj komunumoj defias kutimajn alirojn al la rajtoj de malplimultoj bazitaj sur nacia kontraŭ enmigrinta malplimulta distingo. Mi argumentas, ke ĉi tiuj aliroj ne kontentigas lingvajn postulojn en ĉi tiuj du urboj kaj ke kunteksta aliro pli taŭgas por prilabori la koncepton pri la agnosko de lingvaj rajtoj. 


\section{Address for correspondence}

Iker Erdocia

Dublin City University

School of Applied Language and Intercultural Studies

Glasnevin 9

Dublin 9

Ireland

iker.erdocia@dcu.ie

(D) https://orcid.org/oooo-0oo3-2459-1346

\section{Publication history}

Date received: 30 August 2019

Date accepted: 16 April 2020

Published online: 24 September 2020 